\title{
Development of SMASH Skills Training Model on Volleyball Based on Interactive Multimedia
}

\author{
https://doi.org/10.3991/ijim.v14i06.13405 \\ Muhammad Suhairi ( $\left.{ }^{\bowtie}\right)$ \\ Universitas Negeri Jakarta, Jakarta, Indonesia \\ IKIP PGRI Pontianak, Kalimantan Barat, Indonesia \\ suhairims27@gmail.com \\ Moch. Asmawi, James Tangkudung, Achmad Sofyan Hanif, Firmansyah Dlis \\ Universitas Negeri Jakarta, Jakarta, Indonesia
}

\begin{abstract}
SMASH's skill is a technique that can be done by a person in a hard swooping towards your opponent to produce numbers. Interactive multimedia technology is expected to be a guideline for athletes in looking at more variation models of SMASH. The aim of development research is to produce an interactive multimedia volleyball playing skill training model. The method used in this research is development research design by Borg and Gall. The approach used in this study is a qualitative and quantitative approach. This study is hoped to improve volleyball skills by looking at the interactive multimedia volleyball playing practice model. This study concludes that interactive multimedia-based volleyball skill playing model can be used in the actual application of exercises.
\end{abstract}

Keywords-Interactive Multimedia, SMASH Skills, Volleyball.

\section{Introduction}

Technology has a very important role for the education process and also provides direction in the development of the world of education. The use of science and technology specifically in the development of packaging for interactive multimedia-based learning resources is needed for learning resources to be packaged in more interesting and more complete forms in their presentation. Multimedia is one of the supporting devices that can be used in this case. This is because multimedia technology includes several aspects that are synergistic, between text, graphics, static images, animation, film and sound. Multimedia technology will bring the new revolution of sport education, education thought and education theory in colleges and universities during the multimedia period. Sport education need to gripe the chance to change the traditional education mind. In colleges and universities, bring multimedia technology into the education, rich the teaching content, combine various media techniques to arouse students' learning interests with energy application to the teaching activities then to improve sport teaching in colleges and universities [1]. Understanding multimedia can be different from the point of view of people different. In general, multimedia is relat- 
ed to use of more than one type of media to present information. Multimedia in learning produces visual information that is already well known in the learning process. With average abilities, people learn $1 \%$ through what they feel, $1.5 \%$ through what they touch, $3.5 \%$ through what they smell, $11 \%$ of what they hear, but $83 \%$ of what they see [2]. This research also found that memory levels were $10 \%$ of what they wrote, $20 \%$ of what they heard, $30 \%$ of what they heard and saw $50 \%$ of what they saw and heard, $70 \%$ of what they heard and discuss [3]. The utilization of multimedia tools can offer a flexible way for players understand the actions for the taught skills. With this in mind, a deeper insight about the use of multimedia tools in sport [4]. Multimedia teaching systems can effectively achieve resource sharing. Without space and time limits, students can rationally manage their time according to their time [5].

Through multimedia in the form of images, animations, and videos, supporters of interesting and attractive teaching and learning activities [6]. In his research stated that one of the right media and can be used in facilitating the learning process of volleyball is with the help of learning multimedia in the form of CD (Video Compact Disck). Multimedia learning is the type of learning provided. Students will be able to use this multimedia learning as a source of independent learning [7]. Multimedia technology brings a new revolution in sports education, educational thinking and educational theory in colleges and universities. Sports education needs to change from the mind of traditional education. In college, multimedia technology in the field of sports has an impact on education, many contain the content of the teaching and learning process, combining various media techniques to trigger students' interest in learning with applications so as to energize teaching activities then improve sports teaching in higher education. The appropriate use of media adds to the usefulness of a technology where in education it is inseparable from touch and technological progress. Many benefits can be obtained in the use of multimedia technology because this multimedia technology is able to overcome learning difficulties. States that the use of interactive multimedia in learning is also very possible to improve the expected thinking skills. In general, the benefits that can be obtained through the use of interactive multimedia is that the learning process can run more interesting, more interactive, the amount of teaching time can be reduced, the quality of student learning can be improved and the teaching and learning process can be done anytime, and can improve students' reasoning abilities [8]. Furthermore, the use of multimedia is aimed to overcome the limitations of space, time, and distance during the learning and training process [9]. Volleyball is a complex sport, so in volleyball learning if a teacher is lacking in developing creativity, students will have less of interest in participating in learning process. in the game of volleyball smash is a punch technique that is most needed. The effectiveness of the smash is influenced by physical ability and mastery of attack skills. [10]. It is expected that interactive multimedia in training or learning will be more effective and efficient so that achievements in the field of sports can be maximal or achievers especially in mastering the skills of playing volleyball. Mastery of volleyball skills is needed to make the game can run well. The skills can be in the form of skills: service, bottom pass, top pass, smash and block. Smash is a swooping, sharp and fast punch. By forming a punch attack hard when the ball is on the net, to be inserted into the opponent's area. The display of volleyball skill training models with print media and 
interactive multimedia Compact (VCD) outside of hours of practice in a relaxed state is expected to be able to help the process of understanding the concept of volleyball playing techniques so that the field can see the training model showing the skill of playing volleyball and for novice players, it will increase their knowledge by watching various techniques of playing volleyball well.

The following is a comparison of the renewal of the learning model (old training model) and the new one with interactive multimedia-based.

Table 1. Comparison of renewal of old and new training models with interactive multimediabased.

\begin{tabular}{|l|l|}
\hline \multicolumn{1}{|c|}{ Old } & \multicolumn{1}{c|}{ New } \\
\hline Train based on the experience of the coach & Use a volleyball guidebook \\
\hline There is no interactive multimedia video & There is interactive multimedia video \\
\hline $\begin{array}{l}\text { Variations The exercises given are not sequential } \\
\text { from easy, simple to complex movements }\end{array}$ & $\begin{array}{l}\text { Using the correct sequence of exercises from easy, } \\
\text { simple to complex }\end{array}$ \\
\hline Monotonous exercise, less fun (lack of variety) & Many choices of variations of practice \\
\hline $\begin{array}{l}\text { Athletes or students do not know previous experi- } \\
\text { ences }\end{array}$ & $\begin{array}{l}\text { With video athletes or students can find out the } \\
\text { model that will be applied during training }\end{array}$ \\
\hline Limited learning athletes (only in meetings) & $\begin{array}{l}\text { Student athletes can learn more about the movements } \\
\text { and techniques of volleyball training offline. }\end{array}$ \\
\hline Access dependency & No dependency access (can be accessed offline) \\
\hline There is no complex tutorial (VCD and textbook) & $\begin{array}{l}\text { With multimedia VCDs and textbooks athletes or } \\
\text { students can study independently }\end{array}$ \\
\hline
\end{tabular}

Related to the information, it shows that it is necessary to develop an interactive multimedia-based training model which can later be used as a solution to facilitate students in learning to play volleyball more effectively.

\section{$2 \quad$ Literature Review}

Research and development (Research and Development) according to Borg \& Gall is a process used to develop and validate educational products. Development research finds development patterns, sequences of growth, change and especially has the intention of developing teaching materials for universities. Model development is the result of research oriented to product development results. A model is a description of a mindset. A model usually describes the whole concept that is interrelated [11]. This Development Model uses a system approach model, namely by principle, a stage will receive input from the previous stage and produce output for the next stage, so that all components work together to produce an effective learning [12]. Also explained that research and development is a process or steps to develop a new product or perfect an existing product which can be accounted for. Interactive multimedia becomes an application of learning that utilizes technological advancements that can arouse thoughts, feelings, attention, and willingness to occur in learning processes that enhance skills [13]. Is a research method used to produce certain products, and test the effectiveness of these products [14] According to States that development research is a study that aims to develop a new product or perfect an existing product [14]. States 
that "Development research is research that is used to create new products and can develop products that have supported the analysis of needs that contain in the field (observation, interviews, initial needs questionnaire) [15].

Multimmedia is the use of a computer to present and combine text, grapics, audio, and video with links and tools that let the user navigate, interect, create, and communicat" [16]. Multimedia is defined as a combination of several media which is used to convey information in the from of text, graphics or graphic, movie, video, and audio animation. Multimedia includes hypermedia and hypertext. Hypermedia is a presentation media that includes text, silent grapics of animationm movie, video, and audio [17] Multimedia is an integration of two or more integrated media formats such as texts, images, graphics, souds, animations, and videos to feed information into computer systems [18]. This integration as a whole displays information, massages, or lesson contents. Throught these combined media, learning activities are rendered more interactive and reflect everyday life experience. Multimedia is a combination between several documents, text, art, sound, animation, and videos that are delivered through computers or electronic and digital equipment [19]. Smash is a way to play the ball efficiently and effectively in accordance with the rules of the game to achieve a hard hit aimed at releasing an opponent's game to produce points [20].

\section{Methodology / Materials}

Development research is a research approach that is linked to work design and development and has a purpose for designing in a training environment and strives for a scientific understanding of fundamentals.

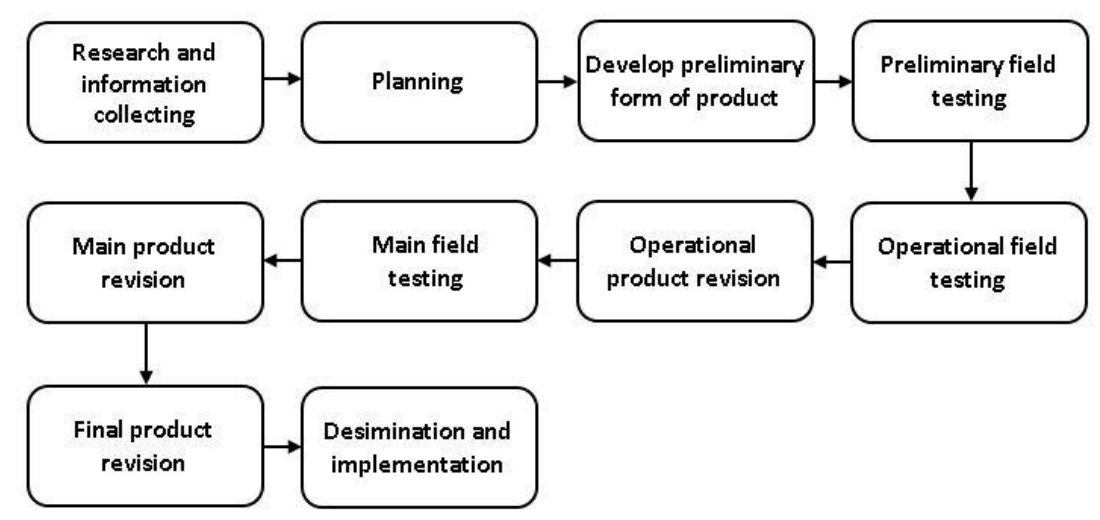

Fig. 1. Stage of Design Risearch and Development Walter R. Borg and Meredith D. Gall.

Components in system approach models according to Walter R. Borg and Meredith D. Gall consist of 10 stages, namely:

1. Preliminary study (Research and Information Collecting)

2. Planning research 
3. Design development (Develop Preliminary of Product)

4. Early stage trials (Preliminary Field Testing)

5. Revised Limited Field Test Results (Main Product Revision)

6. More extensive product testing (Main Field Test)

7. Revised Result of Broader Field Test (Operational Product Revision)

8. Feasibility Test (Operational Field Testing)

9. Final Revision of Final Product Revision Results

10. Dissemination and Implementation of Final Products (Dissemination and Implementation)

Based on the understanding of the development of learning models, there are at least four characteristics, namely:

1. Goal oriented

2. Conditions

3. Systematic

4. Evaluation and revision

Each model designed and developed is preceded by the existence of a clear objective formula.

Research on the development of interactive multimedia volleyball skills training models specifically has several objectives including:

1. Develop a design plan for interactive multimedia volleyball skills training models

2. Obtain empirical data about the effectiveness and efficiency of the results of developing interactive multimedia volleyball skills training models.

The development research procedure basically consists of two main objectives, namely developing the product, and testing the effectiveness of the product in achieving the goal. Adaptation is realized in the form of technical planning goals and types of activities to be carried out in each stage. If the ten steps of research and development are followed correctly, it will be able to produce an educational product that can be accounted for. These steps are not the standard things that must be followed. It can be adjusted to the needs of the researcher. The characteristics of the model developed are training models of interactive multimedia volleyball smash skills specifically having several objectives including:

1. Develop a model design of interactive multimedia volleyball skills smash training

2. Obtaining empirical data about the effectiveness and efficiency of the results of the development of an interactive multimedia volleyball smash skill training model.

\section{$4 \quad$ Results and Findings}

The results of the development of this interactive multimedia-based volleyball smash skill training model are products in the form of printed books and * .exe soft files which are packaged in the form of VCDs. Interactive multimedia volleyball 
based smash skills training models include, text, images, animations, and videos as well as knowledge quiz score analysis of volleyball. The research implementation of this interactive multimedia volleyball smash training model is generally divided into eight main stages, namely:

1. Research needs analysis

2. Product preparation

3. Expert validation and phase I revision

4. Small group trials

5. Revisions stage II

6. Large group trials

7. Operational revisions

8. Product effectiveness test

The following will present data on the results of research and development: Table of results can be seen in the attachment.

Table 2. Results of need analysis Analysis of interactive multimedia based volleyball training models.

\begin{tabular}{|c|l|c|c|c|}
\hline No. & \multicolumn{1}{|c|}{ Questions } & Score & Total Score & $\%$ \\
\hline 1. & Have you ever attended volleyball lectures & 60 & 60 & 100 \\
\hline 2. & Are you a volleyball player & 28 & 60 & 46,66 \\
\hline 3. & Do you master all the techniques of volleyball & 24 & 60 & 40 \\
\hline 4. & Does the trainer use a fariative model in practice & 25 & 60 & 41,67 \\
\hline 5. & Is the model used by the trainer already varied & 20 & 60 & 33,33 \\
\hline 6. & Does the coach ever provide interactive multimedia to help you practice & 0 & 60 & 0 \\
\hline 7. & Do you feel the need to develop volleyball skills training models & 60 & 60 & 100 \\
\hline 8. & $\begin{array}{l}\text { Do you feel that there are needs to be an interactive media that helps } \\
\text { you better understand volleyball games and better master their skills }\end{array}$ & 60 & 60 & 0 \\
\hline
\end{tabular}

From the results of the needs analysis above, there are several important points that are key to the need for development to be carried out. Among other things, that:

1. Out of $60100 \%$ students said the trainer had never provided interactive multimedia to help practice

2. Out of 60 students $41.67 \%$ of students stated that the model used by the trainer when practicing was still not varied

3. From 60 students $100 \%$ stated that there was a need to develop volleyball skills training models

4. Of $60100 \%$ students felt the need to develop interactive multimedia volleyball skills training models

Whereas, based on the results of observations conducted by researchers, it has not yet been revealed that the practice media in the form of video and interactive, and the models used still use conventional drill models.

For development planning the researchers worked with multimedia experts, volleyball lecturers, and volleyball coaches with National tutoring, to obtain a training 
model for smash skills in interactive multimedia volleyball. At each stage of research and development, there are design steps and its explanations are described and modified in accordance with the objectives and conditions of the actual research. Following are the stages of the model development plan:

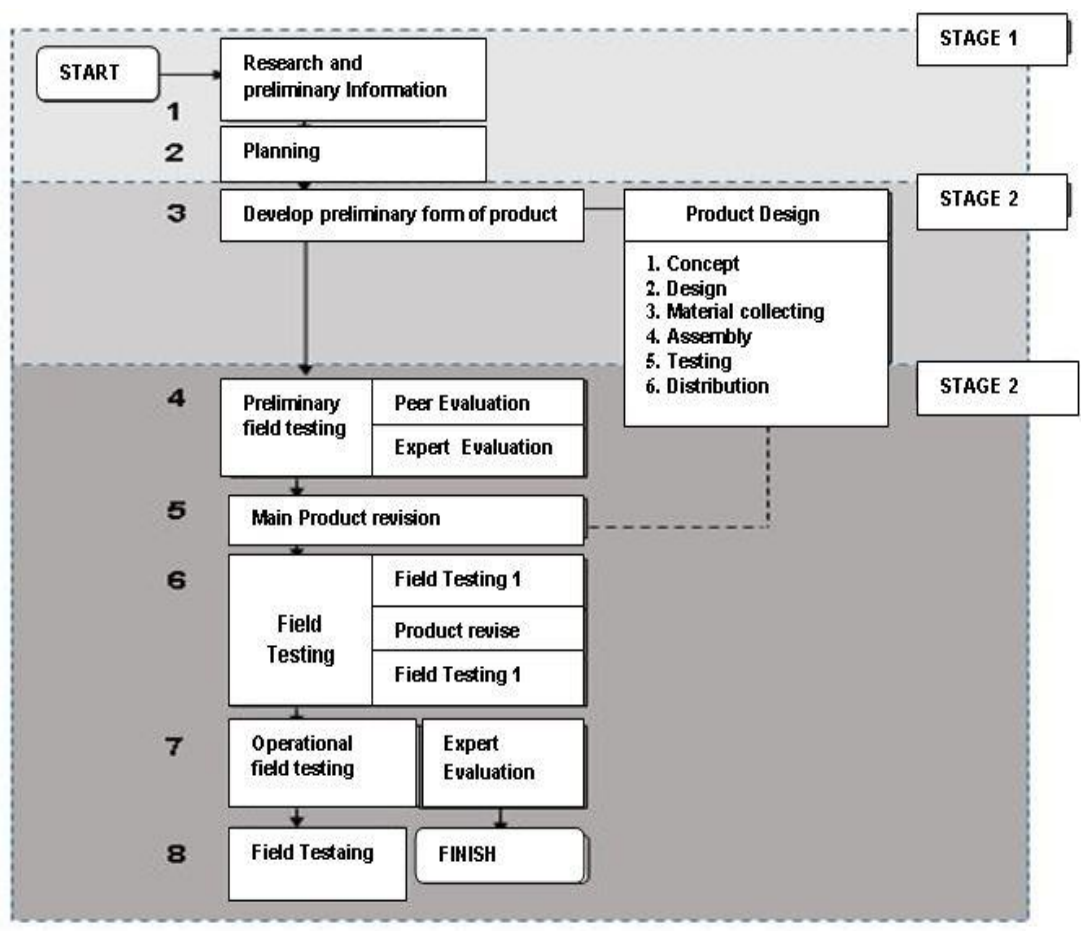

Fig. 2. The flow illustrated above is a path that has been modified by the researcher. The flow used is adjusted to the actual field conditions. Taking into account the availability of time and funds, a number of steps will be modified but not out of the chosen path. The flow is the flow of research and development by Borg and Gall and combined with the development of Luther's interactive multimedia model by Sutopo [21].

The following is a description of the stages of each model development plan:

\section{Stage 1}

1. Conduct research and data collection for initial research or need assumptions for 60 students of Physical Health and Recreation Education.

2. Development planning is done by determining objectives, limiting the scope, and preparing a trial plan.

\section{Stage 2}

1. Develop the initial product, which is then evaluated by 3 media experts, 3 volleyball experts. The development of interactive multimedia products refers to six stag- 
es of multimedia, namely: concept, design, collecting materials, assembly, testing, and distribution.

\section{Stage 3}

1. Small group trials, using 12 student subjects in Physical Health and Recreation Education.

2. Product revision (according to the results of the analysis on small group trials). The product refinement process still refers to six stages of interactive multimedia concepts: concept, design, collecting materials, assembly, testing, and distribution.

3. Field trials (large groups) using 60 subjects of Health and Recreation Physical Education students, with 60 or more respondents.

4. Make product revisions according to the results of large group trials. The product refilling process still follows the interactive multimedia concept: concept, design, collecting materials, assembly, testing, and distribution.

5. Conduct operational trials to determine product effectiveness.

Table 3. Expert Evaluation and revision Phase 1. Interactive multimedia products that have been created are evaluated by media experts

\begin{tabular}{|l|l|c|c|c|l|}
\hline No & \multicolumn{1}{|c|}{ Assessed Aspects } & X & Xi & Percentage & Category \\
\hline & \multicolumn{1}{|c|}{ Multimedia graphic design } & & & & \\
\hline & $\begin{array}{l}\text { The opening view } \\
\text { on each menu is interesting to gener- } \\
\text { ate interest in learning }\end{array}$ & 11 & 12 & 100 & Good \\
\hline $\begin{array}{l}\text { Background design on each menu is } \\
\text { interesting to generate interest in } \\
\text { learning }\end{array}$ & 11 & 12 & 75 & Good Enough \\
\hline $\begin{array}{l}\text { Clarity and accuracy of text size } \\
\begin{array}{l}\text { The image size on each frame and the } \\
\text { icon on the menu is precise and clear }\end{array}\end{array}$ & 11 & 12 & 91,7 & Good \\
\hline $\begin{array}{l}\text { Contrast between background, text } \\
\text { and images }\end{array}$ & 11 & 12 & 91,7 & Good \\
\hline $\begin{array}{l}\text { The size of the video frame is precise } \\
\text { and clear }\end{array}$ & 11 & 12 & 91,7 & Good \\
\hline $\begin{array}{l}\text { The overall exploration of multimedia } \\
\text { graphic design }\end{array}$ & 12 & 12 & 100 & Good \\
\hline $\begin{array}{l}\text { Animated graphics and sound effects } \\
\text { Animation changes the color of the } \\
\text { button when highlighted }\end{array}$ & 10 & 12 & 83,3 & Good Enough \\
\hline $\begin{array}{l}\text { Transition animations between frames } \\
\text { when moving from one menu to an- } \\
\text { other }\end{array}$ & 10 & 12 & 83,3 & Good Enough \\
\hline $\begin{array}{l}\text { Opening animation at the beginning } \\
\text { of the template (when auto run) }\end{array}$ & 11 & 12 & 91,7 & Good \\
\hline
\end{tabular}




\begin{tabular}{|c|c|c|c|c|c|}
\hline & $\begin{array}{l}\text { Animation when closing the applica- } \\
\text { tion }\end{array}$ & 10 & 12 & 83,3 & Good Enough \\
\hline & $\begin{array}{l}\text { The sound effect of the button when } \\
\text { highlighted is clearly heard }\end{array}$ & 12 & 12 & 100 & Good \\
\hline & $\begin{array}{l}\text { The video sound is clear when play- } \\
\text { ing }\end{array}$ & 11 & 12 & 91,7 & Good \\
\hline \multirow{7}{*}{3} & Combination of images, sounds and videos & & & & \\
\hline & $\begin{array}{l}\text { Background color combination with } \\
\text { text }\end{array}$ & 12 & 12 & 100 & Good \\
\hline & $\begin{array}{l}\text { Back sound combination with video } \\
\text { sound }\end{array}$ & 11 & 12 & 91,7 & Good \\
\hline & $\begin{array}{l}\text { Back sound combination with button } \\
\text { sound effects }\end{array}$ & 11 & 12 & 91,7 & Good \\
\hline & Position of each menu & 12 & 12 & 100 & Good \\
\hline & Placement of video frames & 12 & 12 & 100 & Good \\
\hline & Placement of video frames & 12 & 12 & 100 & Good \\
\hline \multirow{5}{*}{4} & \multicolumn{5}{|l|}{ Ease of use } \\
\hline & $\begin{array}{l}\text { How to choose a menu by clicking on } \\
\text { the menu in question makes it easier } \\
\text { for students to operate multimedia }\end{array}$ & 12 & 12 & 100 & Good \\
\hline & How to turn off and turn on music & 12 & 12 & 100 & Good \\
\hline & $\begin{array}{l}\text { The way to get out of the application } \\
\text { is easy to understand }\end{array}$ & 12 & 12 & 100 & Good \\
\hline & Overall operational ease & 12 & 12 & 100 & Good \\
\hline & Total & 271 & 288 & 94,09 & Good \\
\hline & Average & 11,29 & 12 & 94,09 & \\
\hline
\end{tabular}

Based on the evaluation of learning technology developed on interactive multimedia, there are four main assessment variables namely multimedia graphic design, animation and sound effects, a combination of sound and video images, and ease of use.

Based on the data presented above, the results show that interactive multimedia products of volleyball skill training models obtain a total score $(\mathrm{X})$ of 271 from the maximum score (Xi) 288 with a percentage of 94.04, which means that overall the product meets the Good criteria so that it can used in actual learning. Based on the data presented above, the results show that interactive multimedia products of volleyball skills training models are appropriate for use in actual learning. 
Table 4. Trial small groups of interactive multimedia volleyball practice media models.

\begin{tabular}{|c|l|c|c|c|l|}
\hline No. & \multicolumn{1}{|c|}{ Item } & X & Xi & Percentage & \multicolumn{1}{|c|}{ Category } \\
\hline 1. & $\begin{array}{l}\text { Completeness of the smash training } \\
\text { model in increasing students' } \\
\text { knowledge and skills }\end{array}$ & 3.71 & 4 & 92.75 & Good \\
\hline 2. & $\begin{array}{l}\text { The accuracy of the training model } \\
\text { with the concepts of volleyball smash } \\
\text { skills }\end{array}$ & 3.79 & 4 & 94.75 & Good \\
\hline 3. & $\begin{array}{l}\text { The accuracy of the description on } \\
\text { each volleyball training model }\end{array}$ & 3.81 & 4 & 95.25 & Good \\
\hline 4. & Video accuracy & 3.75 & 4 & 93.75 & Good \\
\hline 5. & Multimedia graphic design & 3.78 & 4 & 93.25 & Good \\
\hline 6. & Animated graphics and sound effects & 3.71 & 4 & 92.75 & Good \\
\hline 7. & $\begin{array}{l}\text { Combination of images, sounds and } \\
\text { videos }\end{array}$ & 3.67 & 4 & 91.75 & Good \\
\hline 8. & Ease to use & 3.81 & 4 & 95.25 & Good \\
\hline \multicolumn{2}{|l}{ Total } & 30.03 & 32 & 93.81 & Good \\
\hline
\end{tabular}

The results of the trial of a small group of interactive multimedia volleyball smash training models obtained from 12 students were obtained based on student responses consisting of 8 main variables namely; model completeness, model accuracy, accuracy of description, accuracy of video, graphic design, animation and sound effects, combination of images, sound and video and ease of use that gets a score of (X) 30.03 from maximum score (Xi) 32 which means good average with a percentage of $93.81 \%$ in the good category, so that it can proceed to large group trials.

Table 5. Revision Phase 2 for interactive multimedia-based training models from volleyball experts.

\begin{tabular}{|c|l|c|c|c|l|}
\hline No. & \multicolumn{1}{|c|}{ Item } & $\begin{array}{c}\text { Average of } \\
\text { item }\end{array}$ & $\mathbf{X i}$ & Percentage & Category \\
\hline 1 & $\begin{array}{l}\text { Completeness of training models in increasing } \\
\text { student knowledge and skills }\end{array}$ & 3,78 & 4 & 94,50 & Good \\
\hline 2 & $\begin{array}{l}\text { The accuracy of the training model with the } \\
\text { concepts of volleyball smash skills }\end{array}$ & 3,81 & 4 & 95,25 & Good \\
\hline 3 & The accuracy of the description on each model & 3,67 & 4 & 91,75 & Good \\
\hline 4 & Video accuracy & 3,74 & 4 & 93,50 & Good \\
\hline 5 & E-learning graphic design & 3,79 & 4 & 94,75 & Good \\
\hline 6 & Animated graphics and sound effects & 3,83 & 4 & 95,75 & Good \\
\hline 7 & Combination of images, sounds, text and videos & 3,83 & 4 & 95,75 & Good \\
\hline 8 & Ease of use & 3,83 & 4 & 95,75 & Good \\
\hline \multicolumn{2}{|c|}{ Total } & 30,28 & 32 & 94,63 & Good \\
\hline
\end{tabular}

The revision of phase II of an interactive multimedia volleyball training model obtained from the responses of volleyball experts and media experts consisting of 8 main variables, namely; completeness of the model, accuracy of the model, accuracy of description, accuracy of video, graphic design, animation and sound evaluation, combination of images, sound and video and ease of use that obtains a score of (X) 
30.28 from a maximum score $(\mathrm{Xi}) 32$ which means good average with a percentage of $94.63 \%$ with a good category, so it can be concluded that this product can be used in a larger group trial.

Table 6. Trial Large Group media interactive multimedia volleyball practice media model.

\begin{tabular}{|c|l|c|c|c|c|}
\hline No. & \multicolumn{1}{|c|}{ Item } & $\begin{array}{c}\text { Average } \\
\text { on item }\end{array}$ & Xi & $\begin{array}{c}\text { Percent- } \\
\text { age }\end{array}$ & Category \\
\hline 1. & $\begin{array}{l}\text { Completeness of the smash training model in increasing } \\
\text { students' knowledge and skills }\end{array}$ & 3,88 & 4 & 97 & Good \\
\hline 2. & $\begin{array}{l}\text { The accuracy of the training model with the concepts of } \\
\text { volleyball skills }\end{array}$ & 3,86 & 4 & 96,5 & Good \\
\hline 3. & The accuracy of the description on each model & 3,83 & 4 & 95,75 & Good \\
\hline 4. & Video accuracy & 3,80 & 4 & 95 & Good \\
\hline 5. & Multimedia graphic design & 3,87 & 4 & 96,75 & Good \\
\hline 6. & Animated graphics and sound effects & 3,81 & 4 & 95,25 & Good \\
\hline 7. & Combination of images, sounds and videos & 3,86 & 4 & 96,5 & Good \\
\hline 8. & Ease of use & 3,93 & 4 & 98,25 & Good \\
\hline & & 30,84 & 32 & 96,38 & Good \\
\hline
\end{tabular}

The results of a large group trial of interactive multimedia based volleyball smash skills training model obtained from 60 students were based on the students' responses to Health Physical Education and Recreation IKIP PGRI Pontianak which consisted of 8 main variables namely; completeness of the model, accuracy of the model, accuracy of description, accuracy of video, graphic design, animation and sound evaluation, combination of images, sound and video and ease of use that obtains a score of (X) 30.84 from a maximum score (Xi) 32 which means good average with a percentage of $96.38 \%$ with a good category, so it can be concluded that this product can be used in actual training.

To find out the effectiveness of the product in the form of an interactive multimedia volleyball skills training model which is tested on students whether it is effective or ineffective, then there is data that must be collected, namely data about volleyball game skills for students. This data collection is carried out after a large group test (field test 2). Data collection test effectiveness using the T test with SPPS software. The following data is presented in summary: Data on the value of the pretest of volleyball smash skills from the subjects in the effectiveness test can be seen in the following table:

Table 7. Product Effectiveness Test interactive multimedia based volleyball training model for students who take volleyball training (pretest and posttest)

\begin{tabular}{|l|c|c|}
\hline \multirow{2}{*}{ Respondent } & \multicolumn{2}{|c|}{ Smash } \\
\cline { 2 - 3 } & Total Score & Average Score \\
\hline 40 Students & 372 & 9,3 \\
\hline
\end{tabular}

The posttest value of volleyball smash skills from the subjects in the effectiveness test can be seen in the following table: 
Paper-Development of SMASH Skills Training Model on Volleyball Based on Interactive Multimedia

\begin{tabular}{|l|c|c|}
\hline \multirow{2}{*}{ Respondent } & \multicolumn{2}{|c|}{ Smash } \\
\cline { 2 - 3 } & Total Score & Average Score \\
\hline 40 Students & 663 & 16,57 \\
\hline
\end{tabular}

Based on the data, it shows that the results of the pretest and posttest volleyball skills of the smash test of the pretest obtained a total value of 372 average scores of 9.30 and after the posttest the total value was 663 with an average value of 16.57 . The training model of smash skills in playing interactive multimedia-based volleyball was developed by researchers to help teaching staff (teachers and lecturers), trainers and students, in training volleyball smash skills, increasing volleyball playing skills, and as a reference for volleyball training and learning as well. From the results of previous studies on volleyball learning using interactive multimedia with the subject of field trials (large groups) 30 people and did not test the effectiveness of the product. stated that interactive media products such as volleyball games were declared fit for use in volleyball learning and training [22]. The development of multimedia in the field of sports information is needed as an increase in sports information systems [23].

In the previous research, the researcher considered that the subject was not represented, because the subject used was still relatively small and only focused on the media and the variation of the training model given had not varied. In this study the development of interactive multimedia was carried out featuring media containing videos of various variations and combinations of exercises. The exercise model is more varied so it is not saturated to improve volleyball skills. The subjects of the field trial (large group) of 60 students, and the results of the product effectiveness test on 40 students used with the results of the study stated that the interactive multimedia volleyball-based exercise model is suitable to be used to help improve volleyball skills both for training and learning. Because with the media can increase cognitive, affective, and give birth to the automation movement. Most students are very positive with the use of interactive multimedia in learning [18]. This research and development produces multimedia products Volleyball learning is suitable for use in the process of training, learning and teaching [7]. The skill model of playing volleyball with technology with the help of media allows students, athletes, to be able to effectively and efficiently improve the skills of playing volleyball.

\section{Conclusion}

Based on the data obtained, from the results of field trials and discussion of the results of the study it can be concluded that SMASH's skills in playing volleyball in athletes can be mastered faster by using an exercise model that uses interactive multimedia volleyball-based VCD media. Because with VCD media, athletes can see a series of movements on smash skills outside of repeated training time at each stage of the volleyball smash sequence. So as to provide understanding cognitively, affective and give birth to the movement of automation. The practice model of volleyball playing skills with a touch of VCD technology enables students, athletes, to be able to 
learn and do exercises effectively and efficiently which is used as a literacy enhancer, reference, in an effort to improve volleyball playing skills.

\section{Acknowledgment}

The researchers would like to address their gratitude to Health and Recreation Physical Education Study Program IKIP PGRI Pontianak. Ristek Dikti support and finance Research Doctoral Dissertation. Decree of Strengthening Research and Development Number 3 / E / KPT / 2018.

\section{$7 \quad$ References}

[1] T. Lvhua, "Multimedia application research in sport education," Procedia Eng., vol. 15, pp. 4246-4250, 2011. https://doi.org/10.1016/j.proeng.2011.08.796

[2] N. Vernadakis, P. Antoniou, E. Zetou, M. Giannousi, and E. Kioumourtzoglou, "Comparison of Multimedia Computer-Assisted Instruction, Traditional Instruction and Combined Instruction on Knowledge Acquisition and Retention of Setting Skill in Volleyball," Comput. Teach. New Dev., pp. 133-149, 2010. https://doi.org/10.1007/978-0-387-45951-6_40

[3] G. Shabiralyani, K. S. Hasan, N. Hamad, and N. Iqbal, "Impact of Visual Aids in Enhancing the Learning Process Case Research: District Dera Ghazi Khan.," J. Educ. Pract., vol. 6, no. 19, pp. 226-233, 2015.

[4] M. Al-Asadi, "Soccer Players Skill Development with Multimedia Aid," Futur. Prospect. Educ., vol. 6, no. 5, p. 4, 2006.

[5] Y. Wang, A. Qi, and F. Cui, "Application of the Multimedia Teaching System Based on Real-time Shooting and Production in Martial Art Course," Int. J. Emerg. Technol. Learn., vol. 11, no. 03, pp. 37-41, 2016. https://doi.org/10.3991/ijet.v11i03.5347

[6] Y. N., "Making Of Purchase Media About Sports and Sports Education for The First Medium School Based on Multimedia.," Yogyakarta High Sch. Informatics Manag. Amikom Comput. Yogyakarta, 2011.

[7] L. S. S. P, "Multimedia Development of Volley Ball Material Learning in Corporate Teaching Students For High School Students in Bantul District, Yogyakarta Private Vocational School.," J. Phys. Educ. Sport., vol. 3, no. 2, 2014.

[8] G. Sadam Husein LH, "He Effect Of Interactive Multimedia Use On The Concept Of Skills and Calor Materials Concept And Skills Of Students.," J. Phys. Technol. Educ., vol. 1, no. 3, p. 6, 2015.

[9] S. E., S. DLL, and C. Mims., "Instructional Technology and Media for Learning.," Bost. Pearson Educ. Inc., 2018.

[10] J. M. Palao and D. Valadés, "Validity of the standing spike test as a monitoring protocol for female volleyball players," Biol. Sport, vol. 29, no. 4, p. 281, 2012. https://doi.org/10.5604/20831862.1019666

[11] W. R. Borg and M. D. Gall, "Educational research: An introduction,” 1984.

[12] J. W. Jad., "Special Issue for IETC 2017 Turkish Online Journal of Educational Technology.," Publ. Turkey Turkish Online J. Educ. Technol., 2017.

[13] E. H. Fahmi Arif Ashfahany SA, "Teaching And Health Education Teaching Teaching Materials In Interactive Multimedia For Class Students VII.,” J. Educ. Theory, Res. Dev., vol. 2, no. 2, p. 7, 2017. 
[14] M. A., "Research Methodology in Sports.," 2018.

[15] T. J., "Kinds of Research Methodology: Descriptions and Examples.," Lensa Media Pustaka Indones., 2016.

[16] H. FT., "Multimedia Literacy In: Arnold A, editor.," Multimed. Lit. North Am. McGrawHill Companies, Inc., 2001.

[17] M. Muflihah and H. Aziz, "Developing Interactive Multimedia CD-based Teaching Materials for Teaching Arabic Skill at Arabic Education Department of Islamic State University Sunan Ampel Surabaya," Din. Ilmu, vol. 18, no. 2, pp. 195-210, 2018. https://doi.org/10.21093/di.v18i2.1158

[18] K. Komalasari, "Living Values Based Interactive Multimedia in Civic Education Learning.," Int. J. Instr., vol. 12, no. 1, pp. 113-126, 2019.

[19] S. AH., "Interactive Multimedia with Flash. Sutopo A, editor.," Yogyakarta Graha Ilmu, 2003.

[20] M. E. W. AT, I. Sugiono, and D. Shandy, "Basic Techniques for Playing Volleyball.," Malang Malang State Univ. Indones., 2013.

[21] A. H. Sutopo., "Information and Communication Technology in Education. In: Sutopo $\mathrm{AH}$, editor. Information and Communication Technology in Education.," Yogyakarta Graha Ilmu, 2012.

[22] S. Try Sevita Haryanto WDD, "Development Of Bolavoly Game Learning Using Interactive Media In State 6 State Smp In Situbondo District.," vol. 25, no. 1, p. 6, 2015.

[23] G. P., "Application Research on Multimedia Information Technology in the Universities Physical Teaching.," Open Cybern. Syst. Journal., vol. 9, p. 6, 2015.

\section{Authors}

Muhammad Suhairi Graduate State of Physical Education, Universitas Negeri Jakarta, Indonesia Health and Recreation Physical Education, IKIP PGRI Pontianak, Kalimantan Barat, Indonesia. suhairims27@gmail.com

Moch. Asmawi works in Physical Education Dept at Universitas Negeri Jakarta, Indonesia. asmawi.moch1@gmail.com

James Tangkudung works in Physical Education Dept at Universitas Negeri Jakarta, Indonesia. james24061952@gmail.com

Achmad Sofyan Hanif works in Physical Education Dept at Universitas Negeri Jakarta, Indonesia.ssofyan_dean@yahoo.com

Firmansyah Dlis Works in Physical Education Dept at Universitas Negeri Jakarta, Indonesia. firmansyahdlis.unj@gmail.com

Article submitted 2020-01-30. Resubmitted 2020-02-29. Final acceptance 2020-03-01. Final version published as submitted by the authors. 